\title{
Folk-Linguistic Attitudes in Eastern Massachusetts
}

\author{
Rebecca Day Babcock \\ Literature and Languages, University of Texas of the Permian Basin, Odessa, TX, USA \\ Email: babcock_r@utpb.edu
}

Received 17 May 2014; revised 22 June 2014; accepted 3 July 2014

Copyright (C 2014 by author and Scientific Research Publishing Inc. This work is licensed under the Creative Commons Attribution International License (CC BY). http://creativecommons.org/licenses/by/4.0/

c) (i) Open Access

\begin{abstract}
Folk linguistics attempts to study people's beliefs and attitudes about language through their metalinguistic statements, usually collected in a naturalistic setting. Data was collected in a semistructured focus group setting with 11 white, middle- and working-class participants from Eastern Massachusetts. Participants spoke freely about linguistic topics. The results showed that the group focused their discussion on the speech of politicians (former Boston Mayor Tom Menino to be exact), linguistic status markers, specific features ( $r$ - and g-dropping, broad /a/), regions (local Massachusetts regions and Tennessee), and ethnicity (Black and Hispanic). All topics were introduced by the participants, rather than by the researcher.
\end{abstract}

\section{Keywords}

Folk Linguistics, Language Attitudes, Masschusetts Dialects

\section{Introduction}

Folk linguistics attempts to study people's beliefs and attitudes about language through their metalinguistic statements, usually collected in a naturalistic setting. The present study is based on Bourdieu's conception that language and discourse is "a being-perceived which exists only in relation to perceiving subjects" and "only in relation to agents endowed with schemes of perception and appreciation" (1991: pp. 38-39). The work of Dennis Preston (1986, 1989, 1993, 1994, 1996; Niedzielski \& Preston, 2003) provides a model for this type of investigation. Following Preston, this study seeks to find "the folk theories of language held by real people" (Niedzielski \& Preston, 2003: p. vii) because "what the folk believe about language deserves careful consideration" (p. xvii). Data was collected in a semi-structured focus group setting with 11 white, middle- and working-class participants from Eastern Massachusetts. Participants were prompted with questions such as, "Do people from New Hampshire talk differently?” which provided a springboard for conversation topics. For instance, the above 
question was followed by just four turns of responses directed to the question and then the topics proceeded from Southern accents to Scottish accents, back to New Hampshire and Boston accents and the accents and dialects of several surrounding towns. When conversation lagged, the researcher prompted the participants by asking for particulars about their attitudes toward language and speakers of different varieties. After transcribing the data, I coded for themes of content and arranged those themes into an analytical framework. Since these categories grew out of the present data, they are different from the categories Niedzielski and Preston (2003) presented, which were regionalism, social factors, language acquisition and applied linguistics, and general and descriptive linguistics. The main concerns of the current study group were regional, educational, and ethic markers/stereotypes in speech, which correspond to Niedzielski and Preston's first two categories. Eckard (2008) explains Labov's classic definition of indicator vs. marker vs. stereotype:

Only stereotypes should be at the level of conscious comment for the folk. Indicators have attracted no notice [by the folk] and do not figure in variation across the formality continuum. Markers and stereotypes are variables that have attracted sufficient attention to emerge within those categories in stylistic variation. The difference between markers and stereotypes lies in the level of consciousness: Stereotypes are subject to metapragmatic discussion, while markers are not. (p. 463)

Without a study of folk-lingustics, linguists must only guess what the stereotyped features are, unless linguistically sophisticated respondents are able to identify markers if not by name then by mimicking (such as the use of nonstandard verbs). Below I discuss what the participants perceived those stereotypes to be, and look at their actual use of certain features that relate directly to the topic (i.e. Johnstone \& Kiesling, 2008). I especially looked for mention of specific features (either directly mentioned or mimicked) and specific stated or implied attitudes. The result is a folk-linguistic study based on naturally occurring discourse using ethnographic and focus group methods.

\section{Brief Literature Review}

The study of folk-linguistics was proposed by Hoeningswald (1971) and later taken up by Preston in various studies. Preston (1989) wrote that "impressions, classifications, and caricatures of language and language use" by nonlinguists "are part of the information needed to understand the status of and regard for language use in speech communities" (p. xi). Although Preston often uses maps (i.e. Preston, 1986; Preston, 1996), I have chosen to use open-ended, semi-structured linguistic interviews to collect my data, as was done in Niedzielski \& Preston (2003). My participants also imitated the various dialects they were discussing, and Preston (1993) also mentioned the value of this type of mimicry as data. This study most resembles the folk linguistic work done by Niedzielski \& Preston (2003) and colleagues in reaction to the original idea proposed by Hoeningswald (1971) and in turn begins to answer their call for linguists to engage in more examples of such studies "set in western, post-technological, heterogeneous cultures," in this case, 21st century Massachusetts (p. 32). Just because Niedzielski and Preston engaged in such a study does not make other such studies unnecessary. Just the opposite. More folk-data need to be collected as Niedzielski and Preston intended their study "to help begin the account of linguistic folk belief in a United States setting.” The current study simply attempts to continue that account.

Studies of language attitudes have traditionally used recordings, surveys, and one-on-one interviews. The matched-guise technique, that of playing tapes of the same speaker using two different languages or dialects and then asking respondents to categorize the speakers across various dimensions, was introduced in 1960 by Lambert, Hodgson, Gardner, and Fillenbaum, and is still being used up to the present (i.e. Lai, 2007; Overby, Carrell, \& Bernthal, 2007; Campbell-Kibler, 2008). Studies of language perception have also used maps and recordings and have focused on respondents attempting to determine the ethnicity, class or region of the speaker (Thomas, 2002). Other recent studies that have used maps are Hartley (2005) and Bucholz, Bermudez, Fung, Edwards, and Vargas (2007). Jones (2001) used a one-on-one interview technique to determine the attitudes of English immigrants to their own Americanized accents. I agree with Niedzielski \& Preston (2003) that "overt notions of geographical variation [among other things] based on neither production nor responses to forms, provide a helpful corollary to both production and attitude studies" (p. 41), and that "elicitation and the process of reasoning about language in discoursal settings may be more valuable than the elicitation of static, prepackaged folk belief" (p. 301). The contribution of this study is the content analysis of the topics raised. These topics indicate the areas of concern for these speakers.

In order to explain attitude, I use Perloff's definition, which defines attitude as "a learned, global evaluation of an object (person, place, or issue) that influences thought and action” (2008: p. 39).The classic aspects of attitude 
that I attempt to determine in this study are the COGNITIVE (knowing), AFFECTIVE (feeling), and CONATIVE (doing; Fazio \& Olson, 2003). For the purposes of this study, I framed these concepts as 1) the participants' knowledge of a certain ethnic group speechway, regional dialect or accent, or specific phonological or grammatical feature, 2) their feeling or emotion toward that item, and 3) any behavioral component or result. Whenever I elicited an item of attitude I attempted to cover all three of these aspects, although I was not always successful, and this is not surprising, as Fazio \& Olson (2003) claim that all three aspects will not necessarily be observed, and certain aspects (say, behavior and belief) may even be in conflict.

\section{Method}

Like Niedzielski \& Preston (2003), I decided to collect data in a focus group interview situation of "free wheeling conversations on linguistic topics” (p. xii). ${ }^{1}$ This differs from traditional studies in the following ways: Recorded conversations are usually unguided and spontaneous, language attitude surveys are usually done using tape recorded speech played to judges, and interviews are usually done one-on-one. I decided to break with tradition and follow the lead of Niedzielski and Preston and colleagues in this way to achieve the kind of spontaneous speech Labov sought when he asked people to narrate a near-death experience or define "common sense" (1966: p. 595), and to observe the kind of meta-talk, or language about language that Preston (1996) suggested we study. The focus group conversation was taped and transcribed, and the resulting data consists of 50 handwritten pages of transcription out of almost two hours of talk. I used a qualitative approach to code the transcripts for features and attitudes. I then grouped the themes and arranged them by topic. In focus group research, the topics that participants choose to discuss are the focus of the analysis, and "the results from focus groups are evidence based. It is in sifting through the evidence that the researcher looks for patterns and themes" (Levers, 2006: p. 392).

According to Levers, focus group research is becoming more and more accepted in the behavioral sciences as a way to tap into people's beliefs in a natural, non-threatening environment. She writes, "Qualitative research strategies often are used to obtain phenomenological and existential information about the human condition that, by the very nature of the data, would be difficult or nearly impossible to acquire through quantitatively oriented or conventional statistical means” (p. 385). Language attitude surveys or empirical studies involve the judgment of the researcher as to what will emerge as the important variables. In a study such as this, all the topics and variables come directly from the participants, and thus display their actual concerns, rather than those of the researcher.

When discussing linguistic features and other issues I try to use the terms of the participants, unless a gloss is needed in the interest of clarity. Regular spelling is used unless a dialect feature is salient, in which case I attempt to use a modified orthography based on the accepted values in English for the Roman alphabet to represent it, and when this is impossible, I use IPA phonemic transcription. Conventional orthography and punctuation are also used in the transcripts with the exception of equals signs (=) for latching (a turn that follows the previous utterance with no perceivable gap) and single brackets preceding both utterances ([) in vertical alignment for simultaneous speech. A long dash is used to indicate an utterance that was cut off grammatically either by the speaker or by interruption. Noticeably lengthened vowels are indicated by a colon (:) following the vowel.

\subsection{Participants}

B (researcher), female, 33, graduate student, identifies as being from Massachusetts.

$\mathrm{K}$, female, 29, bar manager and caterer, lives in Allston in an apartment, BA degree, identifies as part Portuguese, Bostonian, and a Marbleheader. (All cities and towns mentioned are in Eastern Massachusetts unless otherwise indicated.)

$\mathrm{J}$, female, 69, retired, works in convenience store, lives in an elderly housing apartment, identifies as Bostonian.

M, male, 39, graduate student at Harvard, lives in Lynnfield in his own house with his wife, G, identifies as Bostonian.

G, female, 38, M's wife, works as a sales rep at Saucony, BA degree, identifies as Bostonian.

A, female, 55, hospital administrator, MA degree, lives in own house in Marblehead with husband, identifies ${ }^{1}$ All participants consented to be interviewed and audiotaped for scholarly analysis. Prior to publication of the results, participants were
offered their choice of a pseudonym and also the opportunity to check over the document. For those under 18, consent was given by a parent. 
as a Marbleheader.

DD, male, 57, works in a warehouse as a “traffic manager”, graduate student in English, A's husband. Had coursework in linguistics as an undergrad.

DE, male, 38, friend, chiropractor, identifies as Bostonian.

E, female, 49, clerical worker in health care company, lives in Ipswich with husband (not present at interview) and two boys, identifies self as Lynner.

BG, male, 13, and DG, male, 11, E's sons.

$\mathrm{S}$, female, 65, retired, BA degree, lives in Rye, New Hampshire with her husband $\mathrm{H}$.

$\mathrm{H}$, male, 65 - 70, retired executive, BA degree, S’s husband.

\subsection{Design}

The subjects were chosen by a sample of convenience and consist mostly of family and one friend. The location and identification, however, are not random. I wanted a sample of people from Eastern Massachusetts who ranged in age, education, and occupation. All participants are European-American. The participants were not played a stimulus recording nor were they asked to draw on maps; they were asked open-ended questions to learn about their linguistic concerns. Since there was no outside stimulus besides the open-ended interview prompts, the participants spoke about features that were most salient and important for them, and that they were most aware of.

Niedzielski and Preston (2003) arranged their results broadly according to region, social factors, language acquisition and applied linguistics; and general descriptive linguistics, such as phonology, lexicon, and syntax, and finally, metalanguage. Presumably this arrangement reflected the concerns of the respondents in their study. I thus present the findings here in a way that reflects the concerns of the folk in the current study. Some topics, like education and ethnicity, were discussed both by my informants and the ones in Niedzielski and Preston's study. Others, like prosody and pragmatics, were discussed by my informants only. Unlike Niedzielski and Preston's fieldworkers, I did not submit sentences to the respondents for grammaticality judgments. Therefore, my results will not follow their categories exactly, nor have I attempted to.

\section{Results}

I found the group focused their discussion on the speech of politicians (Former Boston Mayor Tom Menino to be exact), linguistic status markers, specific features ( $\mathrm{r}$ - and g-dropping, broad /a/), regions (local Massachusetts regions and Tennessee), and ethnicity (Black and Hispanic). All topics were introduced by the participants, rather than by the researcher.

Table 1 characterizes the topics that were spoken about, but since the categories are overlapping, I cannot discuss them in precisely this order, and space prevents me from discussing all categories in great depth.

\subsection{Political Figures}

The original list of focus group interview questions had contained, after Labov, (1966: p. 600), an item about what people thought about certain politicians' speech. I planned to ask about the Kennedys and Tom Menino, but I cut these questions from the interview. Interestingly enough, the group spontaneously started talking about both the Kennedys and Menino. The debate focuses on whether Menino's accent is regional, or due to a disability:

\begin{tabular}{|c|c|c|c|c|c|c|}
\hline & Phonology & Morphology & Syntax & Lexicon & Prosody & Pragmatics \\
\hline Disability & $\mathrm{x}$ & & & & & \\
\hline Education & $\mathrm{x}$ & $\mathrm{x}$ & $\mathrm{x}$ & & & \\
\hline Region & $\mathrm{x}$ & & $\mathrm{x}$ & & $\mathrm{x}$ & $\mathrm{x}$ \\
\hline Race & $\mathrm{x}$ & $\mathrm{x}$ & $\mathrm{x}$ & $\mathrm{x}$ & & \\
\hline Ethnicity & $\mathrm{x}$ & & & & & \\
\hline
\end{tabular}


$\mathrm{K}$ : And even Menino, who is the mayor of Boston-

$\mathrm{J}$ : He cahn't ${ }^{2}$ even talk.

B: You just said there was nothing wrong with a Boston accent.

$\mathrm{J}$ : There isn't.

M: But he doesn't have a Boston accent. He's got a mouth full of marbles.

K: [Mayor Menino

J: [He hasn't got an accent. He's got a problem. A speech defect.= $\mathrm{K}$ :

=Mayor Menino has a very thick Boston accent.

$\mathrm{J}$ : He has a speech defect.

[Researcher talks about how she had planned to ask about this very topic. J repeats her point and several people try to join in but $\mathrm{E}$ indicates that $\mathrm{K}$ hadn't finished her point]

$\mathrm{K}$ : He even said, when he was running on his first campaign, [mimicking Menino's accent] "I ain’t no fancy talker." That was his thing that he=

A:

=That's what I like best about 'im.

K: That's what he ran on, and I said, I was like, “I can't believe that we're gonna have Fred Flintstone as our mayor."

B: Does that make him a Man of the People?

K: Yeah, I think it, what I think it was, I think his handlers were like, “Listen, you've got this Boston accent. You gotta work with it somehow. You know, you're better off just sort of like tryin' to appeal to the masses. Coz we can't smooth it.” I'm sure they tried to smooth it out a little bit. "I ain't no fancy taw kah.”

This discussion revolves around the fact that Menino has a Boston accent, (or speech impediment), but the assumption is that somehow the Mayor should talk properly, and if he doesn't, there must be some explanation, either a physical one like $\mathrm{J}$ offers, or one like $\mathrm{K}$ gives of the spin doctors using the accent to his advantage with the "masses". Obviously, this second explanation would be an example of the use of the vernacular for solidarity. Menino speaks like the people (or, according to the folk, even worse) so they elect him Mayor. While discussing Menino’s accent, no one brought up the point, “Why shouldn't the mayor of Boston have a Boston accent?” There are four manuscript pages of transcript discussing Menino’s accent, and no one asks this crucial question.

Bourdieu (1991) related a similar relevant anecdote, except for in this case the mayor of Pau, the capital of French province Béarn, was touted and applauded for speaking the local dialect at an official function. Since French, the language of power, is what's expected at such an event, the use of the local dialect prompted a positive response, presumably because as mayor, he was expected to know Standard French, but chose to speak the dialect. This is in contrast with Menino, who, it appears, is not expected or even believed by these informants to have command of the standard dialect. Thompson, in his introduction to Language and Symbolic Power, wrote that the Béarnais mayor was "able to draw profit from the hierarchy between the languages" of French and Béarnais, since "as mayor of a large town, he has all the qualifications which guarantee his competence in the dominant language.” Menino, however, is also the mayor of a major city, and a college graduate, albeit from a college with working-class connections. ${ }^{3}$ Thompson went on to write that the Béarnais mayor, "By virtue of his position is able to negate symbolically the hierarchy without disrupting it, to transgress the unwritten law [that French is the only proper language at official functions] and thereby exploit the hierarchy to his advantage in the very process of reaffirming it” (1991: p. 19). Bostonians appear to have an ambivalence about their dialect, and appear to hold contrary stereotypes about working-class and “snooty” Boston accents (Hartley, 2005). This is reflected in the Bostonians' ability to ridicule Menino for his accent, his mumbling, and his malapropisms, while at the same time continuing to elect him as mayor and awarding him a 72\% approval rating (Drake, 2008).

\subsection{Language as Educational Index}

Menino is a graduate of the researcher's alma mater, University of Massachusetts, Boston, which is known as a working-class institution. $\mathrm{M}$, on the other hand, is a graduate student at Harvard. He is concerned about his accent, and this probably has to do with his educational status, and the desire for "linguistic capital" (Bourdieu,

\footnotetext{
$\overline{2 / \mathrm{kant} / \text { is spoken with a broad /a/ (low central vowel) }}$ as mentioned in Nagy, Roberts and Boberg, 2001 and Nagy, 2001.

${ }^{3}$ The folk did not speculate if Menino would speak differently if he had gone to Harvard, but they did discuss the Brahmin accent and called it “that fake Kennedy, weird Kennedy Boston accent” and gave as an example Mayor Quimby on the Simpsons.
} 
1991). This feeling could also be a demonstration of "linguistic insecurity" (Niedzielski \& Preston, 2003). Harvard graduates have certain societal privileges, and along with that, they are expected to talk a certain way. M says:

M: I have tried to pronounce my r's more.

B: Why?

M: Like I said earlier, so I don't have that Boston accent, which I think is sometimes constru:ed as unintelligent.

As a graduate student, he must be "construed" as intelligent, hence the concern with his r's, which the group agrees is the main marker of his Boston speech (although historically socially relevant, the Upper-class Harvard accent or r-less Brahmin speech is on the decline among younger speakers).

As Aitchison (1998) discussed in "Language Change: Progress or Decay?", there are no language features that are inherently "morally wrong," yet M talks of the Boston accent as being "really bad," and compares the fascination of out-of-towners with Boston speech to the public fascination with killers like Kenneth Bianchi and Charles Manson. K replied to him, "You really think the Boston accent is on par with Charles Manson?" Clearly, people make serious value judgments about accents and the stakes are rather high.

The group disagrees about one aspect of morphology and syntax (the narrative present, nonstandard verb forms) as an indicator of education or lack of it:

K: I says, I says, I says.

B: What do you pick that out as?

K: I pick that out as someone who didn't go to college.

B: Do you treat that person any differently?

K: I usually, you know, just dismiss them and run away.

B: Don't make fun of my study.

K: No. I just don't feel differently about them morally.

J: I says, I says. I don't agree with you.

M: I disagree. [Where you grew up

J: $\quad$ [I think they're uneducated, but they also grew up with it.

E. Upbringing

J: There are people who go to college who say, "I says, I says, I says.”

It seems that the folk are implying that verb forms are learned early, in the family or the region, and are not as adaptable to education as other (phonological?) forms.

\subsection{Region}

The folk had many comments about region, mostly cities and towns around Massachusetts, although they named the states of New Hampshire, Maine, and Tennessee as having notable accents, as well as the region of the South and the city of New York. M expresses his understanding of the phonology of the Somerville accent by mimicking it:

M: There were these two girls, and they were from Somerville. [mimics] So I said to her, "You hit my /ka:/" "I didn't hit /jowə ka:/" "F you honey."

Participants never came out and told me "Bostonians drop their $/ \mathrm{r} / \mathrm{s}$ " because, as an insider, I already know that information. Instead, they mentioned trying to pronounce the $/ r / s$ more, and also mimicked extremely stigmatized pronunciations. The above excerpt illustrates r-dropping (deletion of postvocalic /r/; Nagy, 2001; Nagy, Roberts, \& Boberg, 2001), the addition of an additional syllable to words like your /jowə/ and hair /hejə/, and the stereotypical rudeness of Bostonians. The rudeness in this case is tempered by a term of endearment (honey), which demonstrates the ambivalence this speaker feels about the stereotype. Perhaps these people are not rude, just direct.

Another phonological feature that was mentioned is what the folk call "g-dropping" in -ing forms (actually alveolar nasal instead of velar nasal; /n/ for / $\mathrm{n} /$; Fischer, 1958). R- and g-dropping were also the features most discussed regarding the Boston accent in a class-generated language awareness exercise in Language and Literacy (Kutz, 1997: p. 116). Clearly, for the folk, these are the salient features of the dialect. For example, as DD said when I mentioned /r/ or the lack thereof as being a salient feature of this dialect: "It's well known. Everybody talks about it.” The stereotype of g-dropping is even apparent when K talks about going to a Dunkin' Do- 
nuts. Even the name of the typical New England establishment echoes this pronunciation. No one would ever dream of saying "Dunking Donuts," even as a hypercorrection or a joke. This particular group focused on consonants, while Niedzielski \& Preston (2003) found that the folk are more concerned with vowels than with consonants and that speakers in their study did not discuss / $\mathrm{r} /$-lessness.

One feature the group didn't specifically mention but I noticed in the transcripts is the broad /a/: / kant/ instead of /kænt/ for "can't”. J uses this feature, possibly because she is from an older generation. I suspect this traditional New England feature is on the wane, because I didn't hear it used by younger speakers. Nagy, too says this feature is "much less common" (2001: p. 43) than it used to be. Participants did talk about the nasalized, elongated and lowered /o/ of Maine speech, in which they characterized the word corn as being pronounced like /kã:n/.

R-dropping \& narrative present were associated by the group with Somerville speech, with lack of education, and with regional affiliation. R-dropping was also associated with Boston, Gloucester, and Maine speech. Other features that participants associated with particular regions were h-dropping (England); presence of postvocalic /r/ (Marblehead, ${ }^{4}$ Randolph); mumbling, not enunciating, slow rate, potato in mouth, singsong, nonstandard grammar (Southern States); sharp, clicky talk (Revere); vowel changes, like an extremely lengthened, heightened, rounded and off-glided vowel in /kU:ofi/ coffee and syllable addition (dipthongization) /heja/ (two equal syllables) hair (South Boston); nasality, r-dropping, and short “oo" /spUn/ spoon (Maine).

Certain places were mentioned as being typical areas having nonstandard speech. One respondent said, "It's the smaller communities," but actually, these working-class communities probably have relationships that are multiplex. South Boston is one example, as this is a city neighborhood with a "small town" feel. Neighbors are related, they spend free time together, and they often work together, or are unemployed like the Belfast residents Milroy (1987) described. Actually, since South Boston is an Irish community, it has much in common with Milroy's Belfast. Somerville was also mentioned by participants. While hardly a "small community," it is the most densely populated city in Massachusetts. I would hazard a guess that this population density would imply relationships are more multiplex, resulting in more non-standard features.

Participants could mimic features better than they could put them into words, which is to be expected. Several times they mentioned specific towns and connected them with certain features.

B: Why is the Randolph accent different?

G: I didn't think it was.

M: I think DE is right. [Once you hit Boston and north, forget it.

K. [Swampscott is different from Lynn

DE: I get what you're saying “youse guys.”

K: Yeah [laughter]

K: That's $/ \mathrm{mefad} /{ }^{5}$

B: That's what I'm asking. Can you pick, can anyone pick it out by neighborhood or by town?

M: [Oh, yeah.

$\mathrm{K}:\left[\right.$ Yeah. $\quad / \mathrm{Mef} / /^{6}$ The [unintelligible] is much sharper.

M: Revere, Everett. [All those.

$\mathrm{K}:$

[Revere is much sharper. Revere is like Click, click, click, click.

B:

E. Dorchester.

[Give me specifics. Give me specifics.

M: All the-- I'll give you specifics. The heading are=

A: $\quad$ =Ebonics=

${ }^{4}$ The issue of the presence of postvocalic / $\mathrm{r} /$ in Marblehead speech is both interesting and controversial, and could be the topic of a separate paper. I had originally thought that this feature was the result of the influence of "outsiders" who tend to move in to Marblehead, but I came across an article in a local style magazine (Burke, 2008) claiming that the presence of /r/ in Marblehead speech was due to the influence of the dialect of Cornish settlers. I since have spoken to several local historians (Judy Anderson, Bob Booth, and Bette Hunt), and Booth (personal communication) claims that the original settlers of Marblehead were from Dorset, Devon, and Somerset, with a few Cornish families who brought their $\mathrm{r}$-ful speech with them, but nowadays it is almost gone. It is not clear from Matthews (1939) if pronounced postvocalic /r/ was a feature of $17^{\text {th }}$ century Southwest speech, and in any case it will be impossible to prove or disprove historical pronunciation based solely on written records (Grund, 2007). But it does appear that postvocalic $/ r /$, or at least r-colored vowels, were present in $19^{\text {th }}$ and $20^{\text {th }}$ century Cornish dialects of English (Wakelin, 1975).

${ }^{5}$ A local stereotyped pronunciation for Medford.

${ }^{6}$ Another form of the stereotyped pronunciation. 
M:

$\mathrm{K}$ :

[Dorchester

$\mathrm{M}$ : [Everett, Somerville=

$\mathrm{K}$ :

M: Southie, Malden, Revere.

=Southie, Dorchester

Presumably these are the areas with the strongest or most unique accents. In this case, the features include phonology and perhaps prosody (sharp, clicks). "Blue collar" (working class) communities are pointed out as exhibiting more nonstandard features in the dialect.

The group explained that in their society, class or social status is marked by location of residence. There is a hierarchy of towns and each has a status level attached to it. E, who lives in Ipswich, which is considered one of the middle status towns, is originally from Lynn, ${ }^{7}$ perhaps the lowest place in status, and still identifies herself as a Lynner: "I say Lynn because that's where I was born and grew up. Even though people don’t like Lynn. I am a Lynner, and that's all there is to it.” She shows a mixture of pride, and in-your-face honesty. Contrast this with A, who was born in Peabody and grew up in Salem (both middle status), but identifies herself as a Marbleheader (high status). K, too, was born in Lynn but doesn't actively identify with it. The group, however, refused to link speech with socioeconomic status. They linked speech with education or intelligence, race or ethnicity, and location. And, as mentioned above, they directly link town of residence with status. A said, "When you talk about how you identify yourself socioeconomically, I think around here people assume the socioeconomic group [by the town's status]."

Regions outside New England were discussed only briefly. At one point, BG tried to get DG to imitate a friend from Tennessee. He refused to, but said, "He doesn't talk like us. He talks with, like, a Tennessee accent." Then their mother, E, began discussing how she was very frustrated talking to the Tennessee boy's mother because of the slow prosody of her speech: "I'm like, oh, please, I just wanted her to get on with the subject...she was very slow.” E feels the Tennessee mom is “a nice person, [but] I wouldn't call her on the phone!” This is an example of knowledge, feelings, and actions as described by Perloff (2008). She believes the Tennessee mom talks too slow; therefore, she feels frustrated, and her behavior is affected in that she wouldn't call the woman on the phone. She makes it clear that she likes the woman: "She's a nice person." The implication is that a phone call with such a slow talker would just be too exasperating. Giles and Powesland (1975: p. 4) mention studies where decreased rate of speech was associated with increased ratings of benevolence ("She's a nice person.”) and decreased ratings of competence (“Oh, Please...just...get on with the subject.”). Fridland \& Bartlett (2007) discuss the stereotype of the "friendly but unsophisticated Southern country bumpkin" (p. 38). The folk-linguistic data presented here confirm these findings.

For these participants, location identification is relative. For instance, DE mentions that when outside Boston, he'll say he's from Boston, but within Boston, he'll get a very different reaction if he says he's from Marblehead or Lynn (which are only a few miles apart but fall on the extreme ends of the status continuum). Since I live far away from my home town, I identify myself as being from Massachusetts, because like K, I identify both as a Marbleheader and a Bostonian. K tells an interesting anecdote about how location can influence identification:

$\mathrm{K}$ : When we were in Spain, no one knew where Boston was, so we would tell everyone we were from New York. That was years ago. But when Mom n’ I were in Turkey, where we were warned that they were going to kill American tourists, so we were on vacation and so everyone said, "Say you're from Canada," because they got the [unintelligible] or whatever it is, and they're gonna kill all American tourists, so we had to go through a metal detector--

A: We were the only two tourists in the whole Istanbul.

$\mathrm{K}$ : So, we're in Istanbul and we're in the taxi and the taxi driver's like, "Oh, where are you from? You speak English.” And my Mom says “Oh, the States.” And I pinch her. Coz you're supposed to say and [he] was like, "Oh, where in the States?” and she said, "Canada.”

I quote this story for its use of relative location, and also because K uses the narrative present. Earlier in the interview she had picked out this feature as sounding uneducated, and identified it with Somerville speech. In fact, she lived in Somerville for a number of years, but doesn't identify with it. This tendency was discussed by Chaika (1994): “[T] he features that people most disvalue in themselves, they also disvalue in others, even when

\footnotetext{
${ }^{7}$ The famous rhyme goes, “Lynn, Lynn, the city of sin/You never come out the way you went in.”
} 
they are unaware, as they usually are, of how they are really speaking” (p. 100).

\subsection{Ethnicity}

In relation to Hispanic speech, both $\mathrm{E}$ and $\mathrm{S}$ express frustration dealing with people on the phone who speak Spanish-accented English: ${ }^{8}$

E: It's very frustrating. you pick up the phone and you call, like your health insurance. And you get somebody, and they don't speak English. You just get so frustrated. Coz they don't take the time. They're in this country how long?

I have noticed when the folk talk about someone who "can't speak English" what they are referring to is a person who uses a non-native accent or an ethnic variety, such as Chicano English. When I asked her if this affected her feelings, beliefs and behavior she replied, "When I make a phone call and I get someone on the other end I can't communicate with, I'm very frustrated. I'm very mad that they're in that job, and it makes me think the company is paying them very low—a very low pay—coz they're just putting anyone—anyone—on that phone. I don't have a good attitude towards the company."

$\mathrm{E}$ is concerned with professionalism because she deals with customers on the phone at her work. And as she mentioned earlier in the conversation, "I'm more polite to people I work with, coz that's my income." She strives to do a good job at work, but to her, these people don't "take the time." She and DD agree that employers are less particular about the language people speak in lower-paying jobs. E understands this, and she implies that their pay must be "very low" indeed if pay level is directly related to the standardness of speech. Clearly, if people are receiving "low pay" they must be members of a group with lower socioeconomic status, as Hispanics in this context usually are. Niedzielski \& Preson's (2003) informants also linked job pay to standardness of speech, and De La Zerda \& Hopper (1979) found that employers were more likely to desire to hire standard speakers for upper-level jobs, and Hispanic-accented speakers for semi-skilled positions.

As H, S, and E discussed their attitudes about Hispanic English, they began to reflect on how this dialect affects their perception about the speaker's intelligence and competence in a very negative way. S says when she hears someone speaking Hispanic-accented English who "cannot pronounce my name. I become rude. it makes me act in a way that I don't usually act. I become very intolerant," and E says, "I try not to, but then I get so mad.” These feelings of rudeness and anger are directed at the person who doesn't "take the time" to speak in a way that is acceptable to them. In this case they are in the position of paying customers of a business and they feel they should get Standard American-accented English when they call on the phone.

\subsection{Race}

Like the informants in Preston (1994), H and DD (who are White, as were all the informants in this study) discussed African American English (AAE). Unlike Preston's (1994) informants, these men easily agreed that the variety exists, and H categorized it as a "lingo" (referring to lexicon?), and DD called it a "ghetto accent," while Niedzielski \& Preston's (2003) informants called it "slang." Since this is folk linguistics, the folk may not possess the vocabulary of Ebonics and African American English to discuss this variety. I also noted an exchange in an article by Geneva Smitherman (2004) in which a (presumably Black) talk show host called AAE a "ghetto language" (11). Perhaps linguists need to do a better job of educating the public about these issues, which is what Smitherman's article called for.

When I asked DD and H to pick out specific features, they said the most prevalent features of this kind of speech are words like man and dig. To me these features are indicative of lexical items (discourse markers?), from the 1960s; however, Niedzielski \& Preston's (2003) informants also mentioned man as a unique lexical item in Black speech, but in Preston (1994) informants characterized that same item as "old". Another feature DD picked out was a drawl, drawing out words, and I commented that this is a prosodic feature usually associated with southern speech. In fact, I've noticed that Bostonians equate southern speech and Black speech, because many Black people move up from the South, and New Englanders sometimes perceive southern speech and Black speech as very similar. One more feature A picked out was metathesis: aks for ask. This is also a stereotypical pronunciation feature of AAE. Other lexical items the informants associated with African American English were ain't and y'all. The participants also reported that their attitude towards a Black person who spoke Standard English was very good. DD said, “When I'm speaking to a Black man who's speaking an upper level

\footnotetext{
${ }^{8}$ Data was collected in the era before East Indian call centers.
} 
of English, it isn’t long before I forget he's Black. His skin color disappears.” This attitude is very similar to informant M in Niedzielski \& Preston (2003) who referred to "an educated Black person" and that "I don't care what color a person is" (p. 131) implying that if a Black person is educated and speaks standard English then he is no longer perceived as being Black (or different, to these White respondents). This only makes sense if we equate AAE with a negative stereotype and Standard English with a positive one.

$\mathrm{H}$ and $\mathrm{S}$ also mention education as a factor: They are upset that Black athletes, as college graduates, speak nonstandard English. S says,

They go to college and they get an education; why are they speaking that way? My first reaction is: they nevah took an academic subject. They got them to play football, they didn't, you know, these guys couldn't have gone to an English class and speak the way they are speaking. They are speaking grammatically incorrect and they're using terminology, some of it, that is foreign to me. But I just feel they never went to class, you know. So I immediately have a prejudice toward them. Not that they're black, green, or blue. I just think, 'What a shame'. Here, [laughing] they had an opportunity for education and they didn't take it.

Niedzielski \& Preston's informant G also thought it was a "waste” to "get more education [meaning learning to speak Standard English] than someone else" and then not "use it" (2003: p. 149). We can interpolate from this that $\mathrm{S}$ finds this kind of nonstandard speech uneducated. And since these athletes are educated, their speech should be standard. S went to college right out of high school back in the 60s, so we must assume that she's proud that she went to class, and paid attention, and learned to speak properly. S and E are clearly both concerned with the possible exploitation of those whose speech is nonstandard.

$\mathrm{H}$ also mentioned education in relation to Black speech: "In my opinion, the best thing that could happen to show education, is for the Blacks to stop that kind of lingo." He then went on to state that this is in-group speech, and that they should "leav[e] it behind" when speaking to those "outside the ring." He went on to say, "there's already a bias, too much bias in this world for color, but that doesn't help it. When they don't speak the language correctly. They're in the United States, they've gone through the same educational system, but they stick with the lingo.” There is no critique here like S's, that perhaps the educational system cheats Black students. $\mathrm{H}$ does realize that perhaps Black people choose to speak African American English as a way to identify with their community, but he feels they should leave that speech in the community, and not bring it into the larger world, because perhaps their nonstandard language could be a cause for discrimination. These attitudes are very similar to those expressed by Niedzielski and Preston's White participants, who also felt that the use of AAE belies a lack of education, and the use of the Standard by Blacks gives a good impression and causes color to "disappear," as their participant M put it, "You can see a really...educated Black person...I don’t care what color a person is...you can understand them and you can talk to them" (2003: p. 131; emphasis removed). Also, there seems to be an agreement among the attitude that Blacks should "leave [AAE] behind" and sort of a puzzlement to the participants in both this study and Niedzielski \& Preston (2003) of why they would not want to.

\section{Discussion}

Perceptions of out groups' speech were stated as follows: Southern and New Hampshire, low intelligence; New York, rudeness; Tennessee, slow rate; Hispanic, low intelligence and incompetence; British, intelligence; Somerville, lack of education.

Differences of opinion in evaluation were drawn along generational lines. For instance, $\mathrm{J}$ thinks the Boston accent isn't bad at all, while M thinks it's "really bad." Haslett noted, "Individuals who had the highest frequency of nonstandard usage in their own speech were most sensitive to use of those features by others" (1990: p. 331). While M doesn't have a high frequency of these items in his speech, he does have them, and as a Harvard graduate student he is the most concerned with them. $\mathrm{J}$ also disagreed with $\mathrm{K}$ who thinks Bostonians are rude, while $\mathrm{J}$ thinks they're quite friendly. $\mathrm{J}$ also pointed out that people who are college educated also use the narrative present: "I says, I says," while K thinks this is a feature used by the uneducated. J is correct, as most speakers, even educated ones, use the narrative present. As I pointed out above, $\mathrm{K}$ even uses it herself. I think $\mathrm{J}$ is more tolerant of nonstandard features since she is of an older generation and did not attend college. ${ }^{9}$ I hypothesize that for her generation the Eastern Massachusetts dialect was not a hindrance. In those days, people were not geographically mobile, and the jobs were factory jobs, rather than professional jobs where dialect is a qualifica-

\footnotetext{
${ }^{9}$ I have no reference on this other than my personal observations. In many cases I have observed older speakers, especially less-educated ones, evidencing more tolerance toward nonstandard dialects.
} 
tion. Also, those who did not attend college have nothing to prove; there is no need for them to try to sound educated. This is in contrast to $\mathrm{M}$, who feels a need to speak the standard because of his educational status.

The concept of language as job asset was discussed by DD and H. H is also from an older generation, but I believe his sensitivity to non-standard features (and he uses few to none in his own speech) is due to his status as a college graduate. ${ }^{10}$

DD: In the higher socioeconomic levels, you find people move about the country a lot more freely. So, in the higher paying jobs and the higher administrative jobs, you find people from California, from Georgia, from Florida, here working in Massachusetts. And they bring whatever their accent is with 'em. Whereas, someone workin' at the CVS behind the counter, you're not gonna find the company bringing in a checkout girl from, you know, Altoona, Pennsylvania to work here. They all come from the neighborhood. So at that socioeconomic level, those types of accents are more prevalent.

DD, and others in the study, essentially assign people to certain jobs because of their speech, which Chaika says people do "unhesitatingly" (1994: p. 406). Another take on this could be that of the notion of "weak ties" and "strong ties" to the community, as explained by the intersection of social class theory and social network theory (Edwards, 1996):

Working class people develop strong ties to the community culture because they lack the economic means to be geographically mobile, and, thus, become physically and psychologically tied to their neighborhoods. On the other hand, middle class people have looser ties to their neighborhoods because they typically possess the resources and motivation to establish and maintain extra-local affiliations and loyalties. (p. 187)

Of course, these tendencies exhibit themselves in the more highly vernacular speech of those with strong ties to the community, and in the fewer regionalisms and vernacular features in those with weak community ties.

\subsection{Limitations}

One difficulty I found was that I asked for clarification and examples over and over, but the participants were enjoying the conversation so much they just continued on to the next topic of interest. People could name a type of accent or dialect — they could even mimic it—but when asked what specific features make up that dialect or accent they simply couldn't tell me. According to Niedzielski \& Preson (2003), this is to be expected, as mimicry is the best way to elicit "details of varieties from the folk" (p. 111) but that they cannot always retrieve or even describe the specific features they are mimicking. An exception in this study is those features that are saturated in the popular belief, like r-dropping for Bostonians, which could be considered a stereotype. Robinson (1979) would not be surprised by this state of affairs:

We have the possibility of people being able to identify [socio-economic status] on the basis of speech but being unable to represent this know how verbally. This verbal inadequacy could stem from personal ignorance of the facts and an associated technical terminology that has been developed, but it could also represent a universal ignorance at the present point in time. (p. 220)

Niedzielski \& Preston (2003) also mentioned that people may have "folk awareness" (p. 8) of a variable but may not be able to name it, or they may be able to characterize regional differences but not be able to name "specific lower-level features" (p. 9). I found this to be the case.

\subsection{Conclusions}

On the whole, I found that for these participants

- Status is measured by town of residence

- Less educated older speakers are more tolerant of nonstandard features (Boston accent)

- Educated older speakers are less tolerant of nonstandard features

- Educated younger speakers either do not have nonstandard features or negatively evaluate them

- Nonstandard features such as r-less pronunciation are seen as uneducated and regional

- Standard "unaccented" English is seen as indicative of education, high job status, and mobility

- Southern speech and Hispanic-accented speech are evaluated negatively

\footnotetext{
${ }^{10} \mathrm{~A}$ says that $\mathrm{H}$ is of Portuguese descent and his attention to speech might have something to do with the prejudice against the Portuguese in the early to mid $20^{\text {th }}$ century (for evidence that the attitude of Portuguese people being "ignorant” was racially motivated, see Taft 1923/1969 Taft connects lack of knowledge of English among the Portuguese with infant mortality [p. 160]. Also in Taft we find the Portuguese being termed "intellectually barren" [p. 161]). The author, A, S, K, M, and J are of Portuguese descent, but K was the only one to mention it in the interview. As I pointed out earlier, ethnicity is not as important to these people as is the town they live in when determining their status.
} 
- British speech is evaluated positively

- Black English (AAE) is seen as uneducated and inappropriate to use in the larger society

This type of folk-linguistic study is interesting because we get people's candid thoughts rather than carefully censored remarks. However, we cannot expect non-linguists to be able to identify language features. Despite these problems, we can clearly see what these people's attitudes are toward regional and ethnic differences. It's clear that rather than being able to pick out specific characteristics or features of speech, the folk can mimic accents, but on the whole cannot verbalize what makes these accents different. K suggested, "If you had a tape, and you played someone speaking with an English accent and we got to listen to it again, we'd be like, 'Oh They're dropping their r's.' But right now you're making us think of someone speaking an English accent in our head.” This is a valuable critique of the study, but according to Niedzielski \& Preston (2003) perhaps the folk do not have the ability to pick out and name features. Or perhaps, as Bourdieu (1991) claims, that more than an audiotape, the folk would need to see the whole person, the body, the dress, and even then not be able to pick out the specific linguistic features, but rather to be able to perceive a whole.

Further studies could investigate folk beliefs in other regions, and of other classes and ethnic groups. Niedzielski \& Preston (2003) suggest a discourse analysis framework for looking at laypeople's conversations about language. In future studies I would use smaller groups of informants, and record several smaller groups rather than one large one. I would be interested in investigating the folk beliefs about bilingual education, continuing the tradition begun by Hakuta (1986) and Cole (1982; reported in Hakuta), and also to analyze the discourse used when people talk about different languages and varieties. Niedzielski \& Preston (2003) also note the utility of using a non-native speaker as a fieldworker, because informants would then assume much less knowledge on the part of the fieldworker and thus would be more likely to be explicit rather than tacit in their explanations.

I call this group mostly "middle class" but there are elements of classes from professional/executive to hourly worker. If even part of this group can indeed be classified as "petit bourgeois" then their concern with correctness in speech should not be surprising. For the clearly working class members of the group (hourly wage, no college) correctness in their own speech was not as much of a concern as it was for the upwardly-mobile (graduate students). Most of the participants were more concerned with the speech of others. This awareness of insider/outsider status, and concern for the speech of the "other" can be seen as an example of the observation made by Bourdieu (1991) that people have "mental representations" of the other, be it a racial, regional, or ethnic other, based on "language, dialect, and accent" in "acts of perception and appreciation, of cognition and recognition, in which agents invest their interests and their presuppositions” (p. 220). These representations are interesting enough to warrant this study and to encourage others to undertake similar studies.

\section{Acknowledgements}

Special thanks to the participants, to Elizabeth Bilbrey McMellon for help with research and word processing, and to Jelene Ballard, Ward Hoeschler, and three anonymous reviewers for their comments.

\section{References}

Aitchison, J. (1998). Language change: Progress or decay? In V. P. Clark, P. A. Escholz, \& A. F. Rosa (Eds.), Language (pp. 431-441). Boston: Bedford St Martin’s Press.

Bucholz, M., Bermudez, N., Fung, V., Edwards, L., \& Vargas, R. (2007). Hella Nor Cal or Totally So Cal?: The perceptual dialectology of California. Journal of English Linguistics, 35, 325-352. http://dx.doi.org/10.1177/0075424207307780

Bourdieu, P. (1991). Language and symbolic power. Trans. G. Raymond and M. Adamson. Cambridge: Harvard University Press.

Burke, A. (2008). Speaking Marblehead-ese. Marblehead Home and Style, Summer: 38-39, 51.

Campbell-Kibler, K. (2008). I'll be the judge of that: Diversity in social perceptions of (ING). Language in Society, 37, 637-659. http://dx.doi.org/10.1017/S0047404508080974

Chaika, E. (1994). Language: The social mirror. Boston: Heinle \& Heinle.

De La Zerda, N., \& Hopper, R. (1979). Employment interviewer’s reactions to Mexican American speech. Communication Monographs, 46, 126-134. http://dx.doi.org/10.1080/03637757909375998

Drake, J. C. (2008). City worried about crime, but smitten with Menino. The Boston Globe, 20 April. http://www.boston.com/news/local/articles/2008/04/20/city_worried_about_crime_but_smitten_with_menino/ 
Edwards, W. F. (1996). Sex-based differences in language choice in an African-American neighborhood in Detroit. In E. W. Schneider (Ed.), Focus on the USA (pp. 183-194). Amsterdam: John Benjamins.

Http://Dx.Doi.Org/10.1075/Veaw.G16.10edw

Fazio, R. H., \& Olson, M. A. (2003). Attitudes: Foundations, functions, and consequences. In M. A. Hogg, \& J. Cooper, (Eds.), The Sage Handbook of Social Psychology (pp. 139-160). London: Sage.

Fischer, J. L. (1958). Social influences on the choice of linguistic variant. Word, 14, 47-56.

Fridland, V., \& Bartlett, K. (2007). Southern or rural? The social perception of regional vowel distinctions. Southern Journal of Linguistics, 31, 38-62

Giles, H., \& Powesland, P. F. (1975). Speech style and social evaluation. New York: Academic Press.

Grund, P. (2007). From tongue to text: The transmission of the Salem witchcraft examination records. American Speech, 82, 119-150. http://dx.doi.org/10.1215/00031283-2007-005

Hakuta, K. (1986). Mirror of language. New York: Basic Books.

Hartley, L. C. (2005). The consequences of conflicting stereotypes: Bostonian perceptions of US dialects. American Speech, 80, 388-405.http://dx.doi.org/10.1215/00031283-80-4-388

Haslett, B. (1990). Social class, social status and communicative behavior. In H. Giles, \& W. P. Robinson (Eds.), Handbook of language and social psychology (pp. 329-344). New York: John Wiley.

Hoeningswald, H. M. (1971). A proposal for the study of folk-linguistics. In W. Bright, (Ed.), Sociolinguistics (pp. 16-26). The Hague: Mouton.

Johnstone, B., \& Kiesling, S. F. (2008). Indexicality and experience: Exploring the meanings of /aw/ monophthongization in Pittsburgh. Journal of Sociolinguistics, 12, 5-33.http://dx.doi.org/10.1111/j.1467-9841.2008.00351.x

Jones, K. W. (2001). “I’ve called ‘em tom-ah-toes all my life and I’m not going to change!”: Maintaining linguistic control over English identity in the US. Social Forces, 79, 1061-1094.http://dx.doi.org/10.1353/sof.2001.0012

Kutz, E. (1997). Language and literacy. Portsmouth, NH: Boynton/Cook.

Labov, W. (1966). The social stratification of English in New York City. Washington DC: Center for Applied Linguistics.

Lai. M. L. (2007). Exploring language stereotypes in post-colonial Hong Kong through the matched-guise test. Journal of Asian Pacific Communication, 17, 225-244.http://dx.doi.org/10.1075/japc.17.2.05lai

Lambert, W. E., Hodgson, R. C., Gardner, R. C., \& Fillenbaum, S. (1960). Evaluational reactions to spoken languages. The Journal of Abnormal Social Psychology, 60, 44-51.http://dx.doi.org/10.1037/h0044430

Levers, L. (2006). Focus groups and related rapid assessment methods: Identifying psychoeducational HIV/AIDS interventions in Botswana. In C. T. Fischer (Ed.), Qualitative research methods for psychologists (pp. 377-410). Amsterdam: Academic Press. http://dx.doi.org/10.1016/B978-012088470-4/50016-8

Matthews, W. (1939). South western dialect in the early modern period. Neophilologus, 24, 193-209. http://dx.doi.org/10.1007/BF01547845

Milroy, L. (1987). Language and social networks (2nd ed.). New York: Basil Blackwell.

Nagy, N. (2001). "Live free or die” as linguistic principle. American Speech, 76, 30-41. http://dx.doi.org/10.1215/00031283-76-1-30

Nagy, N., Roberts, J., \& Boberg, C. (2001). Yakking with the yankees. American Language Review, 5, 40-43.

Niedzielski, N. A., \& Preston, D. R. (2003). Folk linguistics. Berlin: Mouton de Greuter.

Overby, M., Carrell, T., \& Bernthal, J. (2007). Teachers’ perceptions of students with speech sound disorders: A quantitative and qualitative analysis. Language, Speech, and Hearing Services in Schools, 38, 327-341. http://dx.doi.org/10.1044/0161-1461(2007/035)

Perloff, R. M. (2008). The dynamics of persuasion (3rd ed.). New York: Taylor and Francis.

Preston, D. R. (1986). Five visions of America. Language in Society, 15, 221-240. http://dx.doi.org/10.1017/S0047404500000191

Preston, D. R. (1989). Perceptual dialectology. New York: Walter de Gruyter. http://dx.doi.org/10.1515/9783110871913

Preston, D. R. (1993). The uses of folk linguistics. International Journal of Applied Linguistics, 3, 181-259.

http://dx.doi.org/10.1111/j.1473-4192.1993.tb00049.x

Preston, D. R. (1994). Content-oriented discourse analysis and folk linguistics. Language Sciences, 16, $285-331$. http://dx.doi.org/10.1016/0388-0001(94)90004-3

Preston, D. R. (1996). Where the worst English is spoken. In E. Schneider (Ed.), Focus on the USA (pp. 297-360). Amsterdam: John Benjamins. http://dx.doi.org/10.1075/veaw.g16.16pre 
Robinson, W. P. (1979). Speech markers and social class. In K. R. Scherer, \& H. Giles (Eds.), Social markers in speech (pp. 211-249). New York: Cambridge University Press.

Smitherman, G. (2004). Meditations on language, pedagogy, and a life of struggle. In K. Gilyard, \& V. Nunley (Eds.), Rhetoric and ethnicity (pp. 3-14). Portsmouth, NH: Heinemann.

Taft, D. R. (1969). Two Portuguese communities in New England. New York: Arno and The New York Times.

Thomas, E. R. (2002). Sociophonetic applications of speech perception experiments. American Speech, 77, 115-147. http://dx.doi.org/10.1215/00031283-77-2-115

Thompson, J. B. (1991). Introduction. In P. Bourdieu (Ed.), Language and symbolic power. Cambridge: Harvard University Press.

Wakelin, M. F. (1975). Language and history in Cornwall. Leicester: Leicester University Press. 
Scientific Research Publishing (SCIRP) is one of the largest Open Access journal publishers. It is currently publishing more than 200 open access, online, peer-reviewed journals covering a wide range of academic disciplines. SCIRP serves the worldwide academic communities and contributes to the progress and application of science with its publication.

Other selected journals from SCIRP are listed as below. Submit your manuscript to us via either submit@scirp.org or Online Submission Portal.
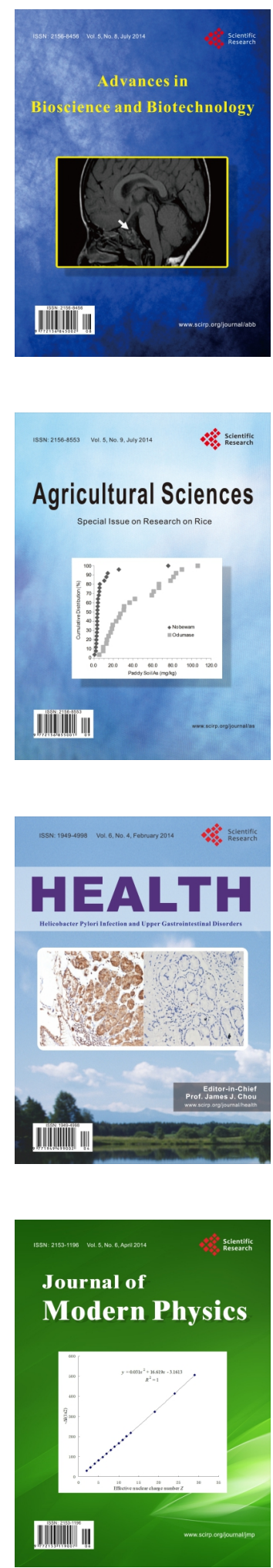
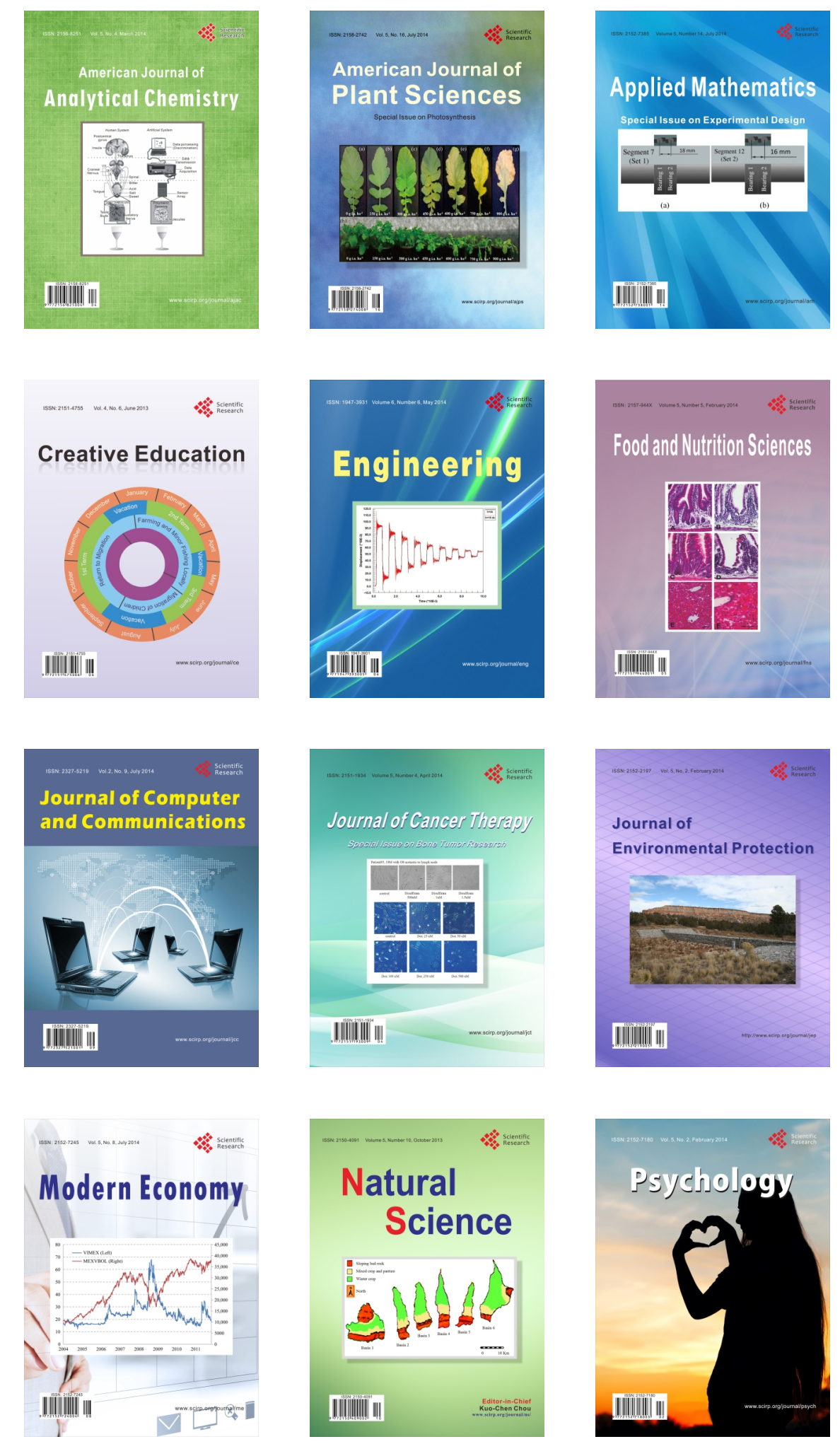